\title{
The potential of a script to portray the acquisition of major household appliances in consumer behaviour research
}

\author{
Alet C Erasmus, Elizabeth Boshoff and GG Rousseau
}

\section{OPSOMMING}

Die aankoop van groot elektriese huishoudelike toerusting word kragtens die belangrikheid van die aankoop, die hoeveelheid geld wat betrokke is en die kort- en langtermyn gevolge van die aankoop, as komplekse hoë-risiko-aankope beskou wat spanning en verwarring by verbruikers kan veroorsaak. Sodanige aankope word dus gewoonlik met groot onsekerheid en omsigtigheid hanteer. Daar is uiteenlopende verslae van hoe verbruikers hierdie onsekerheid aanspreek. Sommige rapporteer meer intense inligtingsoeke en produkevaluering terwyl ander toon dat verbruikers hulle tot meer eenvoudige besluitnemingstrategieë wend.

Tradisionele verbruikersbesluitnemingsmodelle word gewoonlik gebruik as teoretiese raamwerke om navorsing op hierdie gebied te struktureer. In hierdie modelle word die besluitnemingsproses as kompleks en bestaande uit verskeie stadia voorgehou. Besware wat met verloop van tyd teen die gebruik van tradisionele besluitnemingsmodelle aangeteken is in samehang met teenstrydige bewyse van hoe verbruikers onsekerheid tydens besluitneming hanteer, het gelei tot die generering van ' $n$ teks vir die aankoop van groot elektriese huishoudelike toerusting in ' $n$ poging om ' $n$ meer realistiese weergawe van die aankoopproses daar te stel (Erasmus et al, 2002c).

Hierdie bespreking het ten doel om die voordele van ' $n$ teks te identifiseer en verduidelik om verbruikersgedrag beter te kan verstaan en om doelgerigte pogings deur die kleinhandel en industrie aan te moedig om praktykprobleme aan te spreek. Die aankoop van huishoudelike toerusting word eers binne ' $n$ tradisionele verbruikersbesluitnemingsraamwerk bespreek en daarna volgens voorstelling in die teks.

Die struktuur en inhoud van die teks is uiteindelik selfverklarend. Hoewel sekere stappe in die teks groot ooreenkomste met stadia van die besluitnemingsproses toon, lê die unieke eienskappe van die teks verskeie probleme bloot. Ten spyte van die kompleksiteit van die besluitnemingstaak, is inligtingsoeke beperk. Hoewel kleinhandelaars as die ideale platform vir verbruikersopvoeding en verbruikersfasilitering identifiseer word, voldoen dit nie aan verbruikers se verwagtinge nie. Wanneer die inhoud van die geskif met bestaande teorie in ver- band gebring word, kan afgelei word dat verbruikers se hantering van die aankoopproses die gevolg van onsekerheid is. ' $n$ Doelbewuste poging deur die kleinhandel, industrie en belanghebbendes binne die professie verbruikerswetenskap is nodig om praktykprobleme aan te spreek. Dieselfde gevolgtrekkings sou nie op grond van verbruikersbesluitnemingsmodelle afgelei kon word nie.

\section{- Dr AC Erasmus}

- Prof E Boshoff

Department of Consumer Science,

University of Pretoria

\section{- Prof GG Rousseau}

Department of Industrial Psychology

University of Port Elizabeth 


\section{INTRODUCTION}

In contrast to repetitive household purchases such as buying groceries, the purchasing of major household appliances is far more complex and far-reaching in terms of financial implications, performance characteristics and long-term consumer satisfaction (Howell, 1994; Hill \& King, 1989; Cox et al, 1983). It is therefore, in terms of other household purchases, regarded as complex, high-risk consumer decisions. Unfortunately research reports on this topic are difficult to find because the subject has been grossly neglected for many years by consumer science and marketing research. Theoretically there seems to be valid reason to study consumers' approach to the acquisition of major household appliances. Some of the reasons are: the financial implications of such purchases on households in the short- and long-term; the impact of household technology in terms of households' resource management; the consequences of household technology on interior design and planning; impressive changes in appliances as a result of technological development; the effect of global marketing and global concerns regarding energy consumption and waste disposal as well as the acquisition of commodities such as household appliances as a constellation of products that are used to project social status (McMeekin \& Tomlinson, 1998). Firat speaks of a socalled hyper reality that inspires consumers to purchase certain objects (Firat, 1991) while some consumers are called consummate collectors (Hirschman, 1990) because they display material possessions for the purpose of feeling differentiated from other people (Tian et al, 2001). Interior objects, including household appliances are often used to impress others.

In the field of interior merchandise - in terms of its interest to academics, its importance for retail and industry and the impact of the acquisition and ownership of appliances on modern households - the dynamics of electric household appliances in homes and the retail environment present a major, exciting challenge for the future. Professionals and students in the field of consumer science will have to brace themselves for the questions and challenges that accompany change (Burton, 1992). A fresh approach to consumer facilitation seems inevitable and any attempt to improve our knowledge and understanding of the consumer decision-making process will be beneficial to all.

\section{OBJECTIVES}

The objectives of this discussion are to

- give a brief overview of the theory of consumers' approach to the decision-making process when purchasing major household appliances, both as a household expenditure and as a commodity that has more impact and more to offer than obvious functional benefits:

- compare complex consumer decision-making (as is the case during the acquisition of major household appliances) as it is reflected by traditional consumer decision-making models to the presentation of the same purchasing event in a script;

- discuss the advantages of using a script as a more realistic and relevant portrayal of consumers' decision-making behaviour during the acquisition of major household appliances in terms of how consumers, retail and industry as well as professionals in the field of consumer science could benefit.

\section{CONSUMERS' APPROACH TO THE ACQUISITION OF ELECTRICAL HOUSEHOLD APPLIANCES}

\section{Introduction}

The acquisition of major household appliances - in terms of the importance of the purchase, the consequences and the impact of purchase decisions on the short and the long term - is generally described as complex, high-risk decisions. Several arguments support such claims and confirm that consumers generally approach the purchasing process with a notable degree of uncertainty. The conflicting evidence of how consumers deal with these complex decisions in reality necessitate an improved understanding of the entire decision-making process in order to make some suggestions as to how consumers could be assisted.

\section{Electrical household appliances are no longer per- ceived to be luxury items}

Household appliances have become a cultural convenience and a natural necessity in modern homes. Many household decisions evolve around household technology or at least the availability thereof. Its multidimensional profile addresses a combination of consumer needs such as efficient task performance (functional aspects), cost savings, efficient use of time, to communicate emotions, to express family related values and to alter life styles (Cooper, 1994:4, 12; Burton, 1992). Consumers' needs in terms of household technology ultimately depend on circumstances and consumer characteristics: although some still perceive household appliances to be luxury items, others rely on them as necessities (Badami \& Chibat, 1998; Fournier et al, 1992; Joag et al, 1985; Venkatesh, 1985).

\section{Complexity of the purchase decision}

The complexity of the purchase decision is mainly ascribed to extensive technological progress and change over the last two decades. This has resulted in a situation where consumers often consider themselves incapable of evaluating the performance characteristics of new appliances (Niemeyer et el, 1997; Hill \& King, 1989:). Differences in price, design, functional aspects and performance characteristics create confusion and complicate the decision-making process (Du Plessis \& Rousseau, 1999:82-83). Even higher educated consumers require increased cognitive effort to cope with continual change in household technology and consumers are seldom fully aware of the variety awaiting them in-stores when they are con- 
fronted with a purchase (Bettmann, 1993; Fournier et al, 1992). Although there is no doubt that consumers find new ranges of appliances exciting, they generally experience more pressure when there are so many alternatives to choose from (Cooper, 1994:14; Dhar, 1992; Burke, 1990). Making an informed consumer decision where the priorities in terms of functional, aesthetical, cost and other factors are prioritised realistically for a specific household could be problematic (Cox et al, 1983).

Although consumers who are more familiar and knowledgeable about products are expected to have developed more established criteria to cope with product judgments and are expected to apply decision-making criteria more consistently (Burke, 1990; Mano \& Davis, 1990), the relative long expected service life (ten to twenty-five years) for household appliances complicate the decision-making process. Consumers seldom reach the point where they have accumulated enough product experience to consider themselves "familiar" with appliances and consequently seldom feel capable of making purchase decisions without assistance. When objects are perceived to be socially visible products (as could be the case with household appliances) consumers become less confident and react in almost the same way as having no experience at all. The importance of the decision is therefore related to the importance of the consequences of the decision (Chaiken, 1980). The greater the importance of the purchase, the more analytic, systematic, formal and careful the decision-making process is expected to be (Chaiken, 1980). Final choices are often delayed because of uncertainty (Dhar, 1992) and this extends the decision-making procedure.

\section{Risk perception as a result of uncertainty involved}

In most consumer decision situations, explicit, welldefined probabilities rarely exist and are difficult to formulate. The situation is further complicated (as seems typical during the acquisition of household appliances) when consumers are faced with limited and incomplete information about the product (Burke, 1990). This results in uncertainty with regards to the outcome and specific benefits that will emerge from their purchase decisions. For products such as appliances that are expensive, that are regarded as socially visible products, that have to last for a considerable period of time and that are not bought frequently, consumers' uncertainties create anxiety over the possibility of making errors (Hansen, 1992; O'Shaughnessy, 1985). This uncertainty is typically described in terms of various types and levels of risk perception.

Financial risk perception is common when purchasing relatively expensive products. According to Srinivasan (1993) the purchase of an expensive product is usually characterised by a lengthy decision-making process because consumers go through intensive cognitive effort while processing external information and all the influences imposed on them.

Social risk perception refers to tension experienced as a result of consumers' urge to gain the anticipated approval of significant others through the choice of the "right" products (Ungerer, 1999:28-30; McMeekin \& Tomlinson, 1998; Kanwar \& Pagiavlas, 1992; Wright et al, 1992). Fear of bad decisions that might reflect negatively on the decision-maker's ability to handle the situation, enhances pre-purchase tension. The greater the uniqueness, cost, social visibility, complexity and rate of stylistic changes (all of which could be associated with household appliances), the more likely it would be that people will draw inferences from product characteristics about the image of the owner. This increases the pressure to purchase products with specific characteristics such as specific brand names and impressive product features (Toivonen, 1994; Wright et al, 1992). In such instances, social- as well as psychological risk perception affects product evaluation and determine the outcome of the decision-making process. Belk (1988) proposes - according to the existential philosophy of Sartre (1943) - that possessions play a major role in reflecting an individual's identity and that the possibility of making an incorrect choice could have far reaching effects for the consumer - financially as well as emotionally.

The contributing fact that major household appliances are supposed to be functional for ten to twenty years (depending on the type of household, type of appliance and frequency of use) (Ahluwalia \& Shackford, 1998; Erasmus, 1995; Cooper, 1994:4) increases functional risk perception. Households furthermore have to be satisfied with their purchases during this time irrespective of changing circumstances and product developments and this is complicated even further by a lack of knowledge of product developments. As a result of the risk involved during the purchasing of major household appliances, consumers very seldom make purchases without experiencing cognitive dissonance (Hansen, 1992; O'Shaughnessy, 1985).

Confusing evidence regarding consumers' coping with the decision-making process

From what has been reported there is no doubt that the purchasing process is generally approached rather cautiously. Reports on the ways in which the difficulties are addressed, are however, ambiguous and conflicting.

More extensive information search

Some reports indicate more extensive information search and product evaluation. According to Meyers-Levy and Maheswaran (1990) any purchase with high personal relevance or what is perceived to be a high-risk decision, will probably result in detailed processing and a more extensive decision-making process. The conclusion that major household appliances are generally purchased over a longer period of time to allow for more intensive information seeking and processing and the evaluation of potentially suitable alternatives as is the case with other expensive products such as housing (Bozinoff \& Roth, 1983; Bozinoff, 1982) seems valid. There is evidence that task complexity directly affects the decision-making strategies implemented (Burke, 1990). Bettman (1993), for example, based on work by himself, Payne and Luce hypothe- 
sized that stress generated during decision-making causes the decision process to be more effortful although it is often more error prone due to less accurate memory recall. D'Astous et al (1989) proceeded with work initiated by Hoyer (1984) who found that consumer decision-making should be viewed taking into consideration the relevant dimensions of a purchase, i.e. frequency of purchase and importance of the purchase. Rousseau (in Du Plessis \& Rousseau, 1999:82) uses a similar analysis and states that the more important a product, the more complex the decision-making process: he reasons that when higher functional, social, personal and financial risks are implicated, consumers usually engage in more extensive external information search and a more deliberative decision-making process. Consumers will therefore devote more cognitive effort to the purchase of a product that is considered to be important. One can deductively conclude that the decision-making process for household appliances should be considered complex and unique and that it is a type of consumer decision that requires specific and more extensive decision-making strategies.

\section{More simplistic decision-making strategies}

Other studies, however, indicate that consumers deal with complex decisions by reverting to more simplistic decision-making strategies. In the eighties, when theorists began to question the rational approach to consumer decision-making, it was found that for many products, consumers spend very little time or do not even engage in some of the sequential activities suggested as being important during decision-making. It was found that many consumers do little or no prepurchase information search and do the minimum of planning prior to entering retail stores (D' Astous et al, 1989). Some researchers even added that consumers do not typically apply an investigative approach to optimise decisions but relied on heuristics that was somehow associated with consumer satisfaction (e.g. a higher price or a reputable brand name).

Instead of increasing effort to obtain more information to handle complex decisions and to cope with uncertainty, consumers often take decision shortcuts (Hansen, 1992).

- They may imitate those who "know" (friends, relatives) and in so doing, depend on perceived success of others (O'Shaughnessy, 1985).

- They may seek advice from trusted others (e.g. friends, salespeople or specialists in the field) because personal information sources are perceived to be more credible than non-personal information sources (O'Shaughnessy, 1985) even though the information shared by friends might be biased and subjective and the salesperson's recommendations might be based on the potential for commission earned through the sale.

- They may use personal (salespeople, friends, product specialists) and/or non-personal (technical data, brochures, magazines) information sources. This is indicative of more extensive informationseeking behaviour but this unfortunately often results in confusion due to an information overload or inability to interpret information (O'Shaughnessy, 1985:310).

- They may revert to the reputation/ the familiar by being brand loyal (Kanwar \& Pagiavlas, 1992) and in so doing neglect objective evaluation criteria.

- They may also neglect objective evaluation criteria by choosing an expensive product assuming that price represents quality (Kanwar \& Pagiavlas, 1992). Because higher prices also indicate affordability and status, emotional aspects become more prominent (Schiffman \& Kanuk, 2000:441).

- They seek guarantees/ reassurance through collecting additional information. According to Sirdeshmukh and Unnava (1992), consumers exhibit some form of insensitivity to missing information as long as they are unaware of what they are missing. When they are alerted about the importance of attributes or when they realize that some information is missing, they become more concerned, however. Consumers' reactions in the market place will thus be determined by general knowledge and experience about products rather than explicitly available information.

- They do comparison-shopping (O'Shaughnessy, 1985) and in effect combine the evaluation process with in-store information seeking.

- They use a legalistic approach to comply with demands of others (e.g. government energy regulations or the demands of a spouse) to avoid conflict with some legitimate authority (O'Shaughnessy, 1985).

- Consumers could even revert to an elementary knowledge structure and base their choices on simplistic criteria deduced from prior personal experiences with the same or similar products (Burke, 1990).

Conflicting evidence on consumer decision-making strategies resulted in the so-called rational consumer becoming the subject of critics. It was then postulated that consumers engage in both cognitive and emotional information processing (D' Astous et al, 1989, Zajonc \& Markus, 1982 in Lofman, 1991): cognitive referring to active, effortful planning and goal-directed consumer behaviour that involves intellectual activity while emotional processing refers to a state of sensory or imaginary evaluation that might have a different effect dealing with the event.

While traditional consumer decision-making models were constructed with the intention to portray the consumer decision-making process and to reflect the various steps of the decision-making process, it is evident that those models predominantly reflect rational consumer decision-making with extensive cognitive involvement.

\section{THE ACQUISITION OF MAJOR HOUSEHOLD AP. PLIANCES WITHIN A TRADITIONAL CONSUMER DECISION-MAKING FRAMEWORK}

Engel et al (1995:473) emphasise that a consumer decision-model is nothing more than a replica of the 
phenomena it is designed to represent and that it specifies the variables, the ways in which they are interrelated and the outcomes when the model is set in motion. Advantages of consumer decision-making models are their explanatory value (to grasp visually how the process proceeds), that they provide a frame of reference for research (to enable the formulation of research priorities) and the provision of a basis for management of information systems (by retail and industry in order to provide insight for marketing strategy). Consumer decision-making models provide broad, organized structures that reflect the basic process of consumer decision-making from different viewpoints and within different contexts. Some of the best known consumer decision-making models are the Nicosia model (1966), Howard and Sheth (1969), Engel, Kollat and Blackwell (1973), Andreason (1965), Hansen (1972) and Markin models (1974) (Firat, 1985).

Traditional consumer decision models tend to portray the process of proceeding through a major purchase decision as a logical problem-solving matter (Cherian \& Harris, 1990). In these models, the decision-making process is depicted as multi-staged and complex and the consumer decision-making process generally consists of three major components, namely input, process and output (Schiffman \& Kanuk, 2000:443). When described in terms of the traditional five step classification problem-recognition (pre-search stage), information search and alternative evaluation form part of the so-called process while choice and outcome evaluation are components of the output (Schiffman \& Kanuk, 2000:444). Such a description is typical of the rational approach to consumer decisionmaking (Punj \& Srinivasan, 1992; Harrel, 1990; D'Astous et al, 1989; Cox et al, 1983) and reflects the cognitive (problem-solving) consumer and to a certain extent emotional consumer decision-making (Schiffman \& Kanuk, 2000:442).

The following would represent a discussion of a complex, high-risk consumer decision as for the purchasing of major household appliances in terms of the five stages of consumer decision-making as suggested by traditional consumer decision-making models:

- Problem-recognition is generally regarded as the event that triggers the purchase decision and is regarded as the pre-cursor of the rest of the consumer-initiated activities. All the other stages of the consumer decision process are sequentially linked to the problem-recognition stage (Du Plessis \& Rousseau, 1999:84; Punj \& Srinivasan, 1992). Problemrecognition indicates a particular want or need (Punj \& Srinivasan, 1992) that has to be satisfied, for example the need to purchase a new appliance. It may also be related to any of the other stages of the decisionmaking process, e.g. how to finance the appliance, which brand to choose, the back-up service et cetera (Du Plessis \& Rousseau, 1999:84). Problemrecognition in terms of the purchase of an expensive durable product can thus be proposed as a comprehensive, intense and unsettling stage that absorbs a fair amount of time and emotional energy to resolve.
- Information search refers to consumers' use of a combination of information sources to facilitate the decision-making process. Apart from reverting to internal (experience/knowledge-based) information, consumers also use external information: some of which are personal (e.g. friends, relatives, reference groups) and others non-personal (e.g. literature, brochures, product specifications, promotional material such as advertisements, economic variables and business activities such as sales) (Du Plessis \& Rousseau, 1999:87; Punj \& Srinivasan, 1992). Although field studies tend to treat all sources of information equivalently, some sources provide more information than others (Ozanne, 1988), some sources are more effective and some exert more pressure (social, psychological or in terms of understandability). While the general purpose of promotional material such as advertisements (a form of information that is readily available) is to inform and persuade (Owen, 1992), friends and family are consulted to share experiencebased knowledge or to approve decisions. Rousseau describes information search as a learning process (Du Plessis \& Rousseau, 1999:87) and emphasizes that a consumer in the end has to be able to comprehend, retain and apply what has been learnt. Unfortunately more is not always better and information search can be tiresome, frustrating and confusing, leaving the consumer worse off than before. Srinivasan (1993) explains that too much and too difficult information might result in an overload and be rejected because it becomes a threat. Sirdeshmukh and Unnava (1992) have also found missing information to dominate consumers' perception of products during the information search process and this emphasizes the importance of knowing what consumers actually want to know before spending a lot of money on marketing and during consumer facilitation.

- Alternative evaluation deals with the examination of products/models and store visits to evaluate product alternatives. Within a typical rational approach, the evaluation of products is influenced by pre-meditated evaluation criteria (Du Plessis \& Rousseau, 1999:88) (e.g. performance characteristics, product dimensions, price, after sales service), preferences (e.g. brand names, design, model), attitudes (e.g. brand loyalty) and motives. Traditional consumer behaviour theories include four basic motives that influence consumers' evaluation of products, namely economic motives (where cost factors are dominant), responsive actions (based on experience and habit formation), psychological drives (including subconscious desires to own a specific type and brand of product and a need for personal fulfillment through a purchase) as well as social goals (these include social visibility and status factors) (Ratchford \& Vaughn, 1989). During a cognitive laden decision, evaluation forms a significant part of the consumer decisionmaking process and could even include modification of evaluation criteria, making compromises and bargaining activities. The evaluation of alternatives is a critical stage of the decision-making process (Du Plessis \& Rousseau, 1999:88). Engel et al (1995:474) refer to it as a rigorous process. 
- Choice refers to the selection of the most suitable alternative from the evoked set of products. Consumers could experience some form of anxiety and even panic at this stage for fear of making the incorrect decision and because of an inability to cope with the decision - especially where complex, durable and high-risk products are concerned (Bonfield, 1989). Consumers can at this point even decide to postpone a purchase. Du Plessis (in Du Plessis \& Rousseau, 1999:89) prefers to refer to this stage as the response stage. Some authors include the effect of the in-store environment, retailer benefits, contribution of salespeople and store image as decisive factors in terms of the final decision/choice when they discuss the concept or explain the model (Du Plessis \& Rousseau, 1999:89; Engel et al, 1995:474) although in-store activities are seldom explicitly stipulated in the model itself. Having gone through the previous stages, choice entails emotional strain, cognitive involvement and time expenditure and refers to much more than a yes/no decision.

- Outcome evaluation or post-purchase response involves a consumer's evaluation of the product (appliance) towards eventual achievement of consumer satisfaction or dissatisfaction or indifference (Du Plessis \& Rousseau, 1999:89). In instances where cognitive dissonance is experienced, consumers generally make an active effort to obtain additional information or approval from others in support of their decision and to balance their psychological discomfort (Du Plessis \& Rousseau, 1999:90). There is enough evidence to believe that consumers are likely to experience cognitive dissonance during the purchasing of major household appliances and that even the post-purchase response stage should be accounted for in terms of time and effort.

One can thus conclude that when researchers use traditional consumer decision-making models to structure research, when retail and industry refer to these models to set up a marketing strategy or when students use these models to get an understanding of consumer behaviour, traditional consumer decisionmaking models create certain expectations as to the extent of the process and the detail involved. Criticism of traditional consumer decision-making models as discussed by Erasmus et al (2001) include objections made by Firat (1985), namely that concepts and variables included in the models and their relationships are assumed; a technological-managerial orientation seems to dominate traditional models and that buyer behaviour instead of consumer behaviour is investigated.

Problems associated with traditional consumer decision-making models (attitude models, multi-attribute models, brand choice models) and criticisms of the models have led to the development of alternatives, for example normative models (Sheth, 1980 in Hill \& King, 1989). A consumer-aid model as an example of a normative model was proposed and then developed by Hill and King (1989) with the exclusive intention to establish a more representative model of consumer decision-making for complex products so that consumer assistance provided by consumer organizations and professionals could be more in line with what happens in real-life situations. They proposed a procedure for the development of a consumer aid model but eventually concluded with a list of limitations that prevent adoption and implementation of the model. Examples include the fact that product category was not considered; that the purchase of many products involve group decisions (e.g. husband and wife collectively) that affect the process; that models will differ for products where price is of major concern and that subjective evaluation criteria such as aesthetic factors and style were overlooked. These limitations can almost without exception be associated with the purchase of major household appliances and consequently disqualifies the use of a consumer aid model for the purposes of describing this particular purchasing event.

\section{THE ACQUISITION OF MAJOR HOUSEHOLD AP- PLIANCES WITHIN A SCRIPT FRAMEWORK}

\section{A proposal to use scripts to reflect purchasing events}

In the on-going debate and research about consumer decision-making, Schurr (1986) suggested the use of purchasing-scripts as more accurate predictions of buyer behaviour. Scripts are knowledge structures that form part of an individual's declarative knowledge and are stored in long-term memory. Scripts (also known as event schemata) are well-known concepts in cognitive psychology and are inter alia defined as a coherent sequence of events expected by an individual in a particular context, involving him either as participant or as an observer (Puto, 1985) and as a "mental picture plus caption" - representing the action sequences, participants, and physical objects found in a particular situation (Abelson, 1981 in Schurr, 1986). The fact that scripts contain generic information, that scripts are temporal in nature and that they are sequentially ordered, initiated the idea to explore scripts as representations of purchasing events. A major advantage of a script is that it is compiled from the perspective of the consumer, which means that a more realistic scenario of a specific event could be obtained.

\section{A theoretical script for the acquisition of major household appliances}

With this in mind, a script for the acquisition of major household appliances within a consumer decisionmaking context that coincided with the basic properties and characteristics within script theory was successfully elicited and generated (Erasmus et al, 2002c) (Table 2; Figure 1). This was done after a thorough study of basic script theory (Erasmus et al, 2002a) and after careful consideration of potential script-elicitation techniques that led to the eventual compilation of a suggested script-elicitation procedure (Erasmus et al, 2002b). Parameters for the interpretation of action strengths are indicated in Table 1 and 
Scene 1: NEEDS ASSESSMENT

NEEDS ASSESSMENT IN TERMS OF EXPERIENCE, PREFERENCES AND ATTITUDES IS DONE JOINTLY BY HUSBAND AND WIFE OR BY THE WIFE

Scene 2: INFORMATION SEARCH

WRITTEN INFORMATION SOURCES, MAINLY PROMOTIONAL MATERIAL SUCH AS ADVERTISEMENTS ARE USED JOINTLY BY HUSBAND AND WIFE OR BY THE WIFE;

PERSONAL INFORMATION, MAINLY RECOMMENDATIONS OF FRIENDS AND FAMILY, BASED ON EXPERI-

ENCE IS

GENERALLY OBTAINED BY THE WIFE OR JOINTLY;

Telephone enquiries are made to several stores (salespeople), mainly by the wife or jointly

Product specific information such as technical information is gathered mainly by husbands

Scene 3: STORE VISITS

STORES ARE VISITED JOINTLY BY HUSBAND AND WIFE:

TO LOOK AT IN-STORE DISPLAYS AS MAIN SOURCES OF PRODUCT INFORMATION WITH ASSITANCE OF SALESPEOPLE

TO COMPARE PRODUCTS IN TERMS OF THE HOUSEHOLD'S NEEDS, PERSONAL KNOWLEDGE AND EXPERIENCE

To obtain price information by looking at in-store displays

To investigate product specifications by consulting appliance manuals (mainly by the husband)

Scene 4: FINANCIAL DECISIONS

FINANCIAL DECISIONS, INCLUDING AFFORDABILITY, MEANS OF PAYMENT, WHO IS RESPONSIBLE FOR PAYMENT AS WELL AS FINANCIAL ARRANGEMENTS ARE GENERALLY DELIBERATED JOINTLY BY HUSBAND AND WIFE IN-STORE OR AT HOME

Scene 5: EVALUATION

A shortlist of suitable alternatives is made jointly by the husband and wife, ${ }^{1}$

Evaluation of product alternatives ${ }^{2}$ is done jointly by husband and wife in-store, or at home;

Stores are compared jointly by both spouses in terms of benefits offered

Scene 6: CHOICE

Final decision of where to purchase the appliance is made jointly by husband and wife

A PRODUCT IS CHOSEN JOINTLY BY HUSBAND AND WIFE

Scene 7: PURCHASING

THE PURCHASE TRANSACTION IS EITHER HANDLED JOINTLY OR BY THE SPOUSE RESPONSIBLE FOR PAYMENT

Scene 8: DELIVERY

DELIVERY IS GENERALLY DONE/ORGANISED BY THE RETAILER

Scene 9: INSTALLATION

The appliance manual is generally studied mainly by the wife, but may also be consulted by the husband if he installs the appliance himself

INSTALLATION IS DONE EITHER BY A TECHNICIAN OR THE HUSBAND

FIGURE 1: $\quad$ EMPIRICAL SCRIPT FOR THE ACQUISITION OF MAJOR HOUSEHOLD APPLIANCES

\footnotetext{
${ }^{1}$ The compilation of a shortlist was prominently mentioned by between $25-39 \%$ of participants and was therefore included in the script. This action probably did not feature in the stage 3 discrimination task because it is difficult to reflect this action through a drawing.

2 The same argument holds as for the previous point (indicated by $40-59 \%$ of participants)
} 
TABLE 1: PARAMETERS FOR INDICATION OF ACTION STRENGTHS IN THE SCRIPT PROTOCOLS

\begin{tabular}{|l|l|}
\hline \multicolumn{1}{|c|}{$\begin{array}{c}\text { Indicative style of } \\
\text { presentation }\end{array}$} & Frequency (\%)** \\
\hline action & $25-39$ \\
\hline action & $40-59$ \\
\hline ACTION & $60-74$ \\
\hline ACTION & $75+$ \\
\hline
\end{tabular}

${ }^{* *}$ Refers to the frequency an action is mentioned. All actions mentioned by fewer than $25 \%$ of participants were ignored as being less prominent in the script.

these parameters are based on frequency distributions of data collected during the script-elicitation procedures.

\section{Interpretation of the script}

A script consists of various scenes that could be associated with certain stages of a traditional consumer decision-making process. Script elements contained in a scene represent only those actions that are relevant to the specific purchasing event (in this instance the purchasing of major household appliances). These elements are sequentially and hierarchically ordered to indicate the flow of activities towards completion of the event. Every scene is characterized by a main concept (e.g. store visit) that indicates the primary actions/elements to be expected in a particular scene. In the script for the acquisition of major household appliances (Table 2) certain scene headers can be associated with and show resemblance to stages of the consumer decision-making as represented in consumer decision-making models. However, elements pertaining to the scenes in the script, redefine the scope of activities expected in a specific scene when compared to consumer decision-making theory.

An indication of the strength of script elements within a scene (Figure 1) indicates the probability of occurrence of actions/elements to allow for differences in decision-making behaviour of different consumers. The indication of person schemata, role schemata and object schemata in their unique interaction throughout the script, define activities relating to the purchasing event in a very specific way. This characteristic is unique to scripts and the lack thereof has been mentioned as a limitation of consumer decisionmaking models (Hill \& King, 1989).

The following discussion of the various scenes in the script for the acquisition of major household appliances confirm the exclusive characteristics of a script to portray a specific event, including only relevant actions and interconnecting schemata to provide a more realistic depiction of the event.

Scene 1: Needs assessment For the scriptelicitation procedure, participants were confronted with the situation where an appliance needed replacement. The needs recognition stage as described in the consumer decision models was therefore partially defined. The general content of needs assessment as described by participants during the script-elicitation procedure can be associated with the first stage in traditional consumer decision-making models, namely problem-recognition keeping in mind that replacement was stipulated as a given situation. In discussions of traditional consumer decision-making models, this stage/scene is described to represent a comprehensive, intense and unsettling situation that might absorb a fair amount of time and emotional energy to resolve (Punj \& Srinivasan, 1992). Contributing factors are indicated to be the complexity of the purchase, the financial implications and various levels of risk perception. The script indicates a joint discussion by husband and wife of the specific needs of the household in terms of product features, personal preferences and attitudes. The involvement of both husband and wife requires the implementation of a specific decisionmaking strategy (autonomous, synergetic, etc.) and a deliberation of the needs, wants and perspectives of both spouses to reach consensus and to avoid conflict. This in itself may be time-consuming. The active involvement of both husband and wife emphasizes the possible effect of decision-making strategies during this stage in terms of reaching an agreement. Modern women's increased occupational involvement and their consequential ability to contribute financially to purchases that were formerly regarded as luxury items but have since become important time and energy saving devices may have a major impact in this scene (Badami \& Chibat, 1998; Fournier et al, 1992; Joag et al, 1985; Venkatesh, 1985).

Scene 2: Information search In the script, information search includes activities dominated by the wife prior to store visits. Although the acquisition of major household appliances is expected to instigate extensive information search to minimize uncertainty and reduce risk perception, the script (Table 2, scene 2) indicates otherwise. This scene reflects limited search in terms of types and sources of information (Erasmus et al, 2002c). Advertisements in newspapers and magazines feature as a main source of information due to the availability thereof while personal information (mainly non-formal and experience related) shared by friends and family are highly regarded because of the practical value and its perceived trustworthiness (Erasmus et al, 2002c). Phone calls to stores complete consumers' information framework that mainly comprises information on brand reputations, performance characteristics, product features, prices and guarantees. The latter is often used as surrogate indicators for quality (Agrawal et al, 1996:424).

In contrast to what is proposed in consumer decisionmaking theory, the script neither reflects lengthy information search, nor difficulty to cope with information or information overload due to a large amount of factual information that needs to be processed. Contrary to what is expected, information search as exposed in 
TABLE 2: $\quad$ THEORETICAL SCRIPT FOR THE ACQUISITION OF MAJOR HOUSEHOLD APPLIANCES

\section{TITLE: PURCHASING SCRIPT FOR MAJOR HOUSEHOLD APPLIANCES}

Person schemata:

Consumer (male, female); Friends; Family; Salesperson; Cashier

Roles:

Consumer; Salesperson; Advisor; Technician; Delivery man;

\section{Object schemata:}

Advertisements; Appliances; Stores; Store display; Instruction manuals; Money; Credit cards; Sales documents; Telephone; Guarantees

\section{Entry condition:}

Household needs an appliance

Consumer has money

\section{Outcomes:}

Consumer owns new appliance

Consumer has less money

Retailer (salesperson) has made a sale

\begin{tabular}{|l|l}
\hline SCENE & \\
\hline Scene 1 \\
NEEDS ASSESSMENT \\
\hline Scene 2 \\
INFORMATION SEARCH \\
\hline
\end{tabular}

SCENE ELEMENTS IN TERMS OF STRENGTH OF ACTION

Needs assessment in terms of experience, preferences and attitudes is done jointly by husband and wife or by the wife

Written information sources, mainly promotional material such as advertisements are used jointly by husband and wife or by the wife;

Personal information, mainly recommendations of friends and family, based on experience is generally obtained by the wife or jointly;

Telephone enquiries are made to several stores (salespeople), mainly by the wife or jointly

Product specific information such as technical information is gathered mainly by husbands

\begin{tabular}{|l|l|}
\hline $\begin{array}{l}\text { Scene 3 } \\
\text { STORE VISIT }\end{array}$ & $\begin{array}{l}\text { Stores are visited jointly by husband and wife : } \\
\text { To look at in-store displays as main sources of product information with assis- } \\
\text { tance of salespeople } \\
\text { To compare products in terms of the household's needs, personal knowledge } \\
\text { and experience } \\
\text { To obtain price information by looking at in-store displays } \\
\text { To investigate product specifications by consulting appliance manuals (mainly by } \\
\text { the husband) }\end{array}$ \\
\hline $\begin{array}{l}\text { Scene 4 } \\
\text { FINANCIAL DECISIONS }\end{array}$ & $\begin{array}{l}\text { Financial decisions, including affordability, means of payment, who is responsi- } \\
\text { ble for payment as well as financial arrangements are generally deliberated } \\
\text { jointly by husband and wife in-store or at home }\end{array}$ \\
\hline EVALUATION 5 & $\begin{array}{l}\text { A shortlist of suitable alternatives is made jointly by husband and wife, } \\
\text { Evaluation of product alternatives is done jointly by husband and wife in-store, or } \\
\text { at home; } \\
\text { Stores are compared jointly by both spouses in terms of benefits offered }\end{array}$ \\
\hline $\begin{array}{l}\text { Scene } 6 \\
\text { CHOICE }\end{array}$ & $\begin{array}{l}\text { Final decision of where to purchase the appliance is made jointly by husband } \\
\text { and wife } \\
\text { A product is chosen jointly by husband and wife }\end{array}$ \\
\hline $\begin{array}{l}\text { Scene } 7 \\
\text { PURCHASE }\end{array}$ & $\begin{array}{l}\text { The purchase transaction is either handled jointly or by the spouse responsible } \\
\text { for payment }\end{array}$ \\
\hline $\begin{array}{l}\text { Scene } 8 \\
\text { DELIVERY }\end{array}$ & $\begin{array}{l}\text { Delivery is generally done/organized by the retailer } \\
\text { INSTALLATION } \\
\text { Installation is done either by a technician or the husband }\end{array}$ \\
\hline Scene 9
\end{tabular}


the script seems uncomplicated and shows little evidence of search for technical information.

Scene 3: Store visits Store visit is an important scene in the script in terms of the range of elements included. This scene is exceptional in the sense that the individual stages in traditional consumer decisionmodels are signified by verbs (information search; evaluation; choice, etc.) that refer to very specific types of activities. The specification of person, decision-making, object as well as role schemata in a script have resulted in this scene being identified by the most salient denominator (in this case, store visit) which eventually integrates various activities (information search, evaluation as well as choice). The script specifies the store as the center of activity. This scene integrates three stages of the theoretical consumer decision-making process to reflect a reality where husband and wife, with limited information at hand, rely on store visits for the information and assistance required to finalize a decision and to complete the transaction. Although the type of information search specified in this scene is still relatively elementary with limited referral to technical information, the significance of the script lies in its ability to indicate the store as the most important source of information (in addition to the non-formal, experience based and often subjective information shared by friends and family) and venue for product evaluation. It further identifies the potential of the retail store as education facility and of the salesperson as consumer facilitator. The content of this scene is informative in the sense that it indicates the manner and time frame in which consumers integrate a multitude of purchase related tasks. Despite the array of decision-making tasks dealt with in-store, the elements contained in this scene do not typify store visits as being complex.

Although some authors include the effect of the instore environment in their discussion of the final choice when they explain consumer decision models (Du Plessis \& Rousseau, 1999:89; Engel et al, 1995:474) in-store activities are seldom explicitly stipulated in the consumer decision model itself. In the script, in-store activities are explicitly identified as a coherent scene prior to the choice scene. This is mainly because of the specific characteristic of a script to identify the relevant script norms and to consequently describe more clearly the what, where and when of a specific scene.

Scene 4: Financial decisions Financial aspects of a purchase are generally considered as an external influence during consumer decision-making that impacts on financial risk perception on the grounds of the relative cost of appliances. It can also form part of the discussion of the choice but specific reference to deliberation of finances in consumer decision-making theory pertaining to its incorporation in consumer decision-making models, is limited. Mention of when and how these decisions fit into the decision-making process (or models), is neglected.

The script, on the other hand, reflects financial decisions as a prominent scene and as a major precursor of the choice that is made. Both husband's and wife's deliberation of affordability (price limitations), method of payment (for example cash or hire purchase, as well as a deliberation of whether the husband, wife or both will finance the purchase) and the consequent arrangement of finances in reaction to their store visit/s are stipulated in a specific scene in the script. The culmination of needs assessment, information search and the store visits enable an estimation of the financial implications of their decision and necessitate ways to address the situation. Instead of interpreting the financial implications of the purchase as an external influence that influences perception and eventually information search, evaluation and choice (a scenario typically deduced from consumer decisionmaking models), financial aspects seem to culminate much later during the decision-making process as a determinant of what is eventually considered to be affordable and how the transaction is to be concluded. Of importance is the fact that financial decisionmaking is a scene in itself rather than an element or sub-scene of another scene. This was confirmed by focus-group discussions during the script-elicitation procedure (Erasmus et al, 2002c)

Scene 5: Evaluation This scene comprises of elements that are generally weaker and probably less prominent than in most of the other scenes (Figure 1). Evaluation is indicated as a task handled by both husband and wife and entails the evaluation of product alternatives, a comparison of retailer benefits (such as discounts, delivery and installation) and the compilation of a shortlist of alternatives by a minority of consumers. During focus-group discussions it became clear that consumers do not really experience an evaluation stage: the process should perhaps rather be described as a search for the suitable appliance that includes evaluation along the way during in-store activities instead of experiencing a separate stage of evaluation where options are compared and eliminated. Wagner and Klein (1993) found that consumers actually use simple agendas to decide - even for complex products. O'Shaughnessy (1985) refers to the interaction of information search and evaluation as comparison-shopping. The fact that all action statements referring to evaluation were mentioned by less than two thirds of the participants during all of the script-elicitation procedures, confirms this conclusion.

Scene 6: Final choice Choice refers to choice of the product and for those who visit several stores, this scene also includes the choice of store that inter alia offers more benefits and best prices. This scene may take place in the store itself or at home and it is dealt with jointly although husbands may strongly influence the amount of money to be spent and insist on certain technical aspects while women tend to dominate the type of machine that is chosen. This coincides with the scenario of needs assessment.

Scene 7: Purchase The actual purchase is made jointly or may be finalized by the individual responsible for payment. At this point all decisions regarding method of payment et cetera are sorted out 
so that this scene merely reflects the action of signing the contract (if any) and paying.

Scene 8: Delivery The majority of consumers indicated or expected delivery of the appliance as being the responsibility of the retailer and in some instances even chose the store that included delivery as part of the deal.

Scene 9: Installation Installation seems to be handled by either the consumers (husbands) or by qualified technicians. In instances where consumers do the installation themselves, the manual is read before installation. Many however only read the manual after installation (probably by those who have the appliances installed by technicians).

\section{ADVANTAGES OF A SCRIPT AS PORTRAYAL OF THE DECISION-MAKING EVENT}

\section{Unique properties and characteristics of a script}

The script, due to the fact that it is generated from the view of the consumer and in terms of the basic characteristics and properties of a script, provides valuable insight into consumers' actual buying behaviour during the decision-making event. The following conclusions made on the grounds of advantages offered by a script are offered to theorists, retail and industry to understand what actually happens during the specific event.

General script content Consumer decision-making models and consumer-aid models provide broad, organized structures that reflect the basic process of consumer decision-making (Burns \& Gentry, 1990; Hill \& King, 1989). A script represents a mental representation of the event from the view of the consumer (Puto, 1985) and reflects the specific content of only one event: in this case the event of purchasing major household appliances.

Ordering of script scenes and elements A script indicates a sequential and hierarchical ordering of scenes and script elements. Although the sequential ordering of steps in decision-making has been criticized in traditional decision-making models (Martin \& Kiecker, 1990), a script compensates by acknowledging that some scenes could occur simultaneously. The indication of object schemata in the script for the acquisition of major household appliances for example revealed that store visit (scene 3 ) could, for some consumers and in certain circumstances, also include evaluation (scene 4) and choice (scene 5) as subscenes. The sequential ordering then only becomes important in the sense that it indicates one scene as a pre-cursor of the other: consumers for example do comparison shopping in-stores before financial decision-making but in reality all actions could take place during a single store visit in a relatively short space of time. This was confirmed by comparing reports gathered through the use of three different script-elicitation techniques as well as a fourth technique where participants specifically had to reconstruct the event starting at a specific point somewhere in the middle of the purchasing event (Erasmus et al, 2002c).

A noteworthy property of a script is that it indicates a hierarchical order of activities of the event (Bozinoff \& Roth, 1983; Bower et al, 1979). In contrast to traditional consumer decision-models that are invaluable in terms of concept formation and to indicate the interaction of concepts when the process comes into motion, a script is a portrayal of reality. The script is a simpler version of the event and only includes actions that are relevant to the event but the empirical script also indicates strengths and weaknesses of individual elements. The so-called core elements (actions that will always occur) thus become evident so that there is a more defined portrayal of how the event is handled by different consumers in different contexts. This for example resulted in the conclusion that for the acquisition of major household appliances, evaluation (scene 6) is less prominent because, for some, evaluation is contained in evaluation shopping (a combined effort during store visit, scene 3). A traditional model only reflects the one extreme.

It is suggested that consumer facilitation and consumer education concentrate on core activities to ensure that efforts are worthwhile and for the benefit of the majority of consumers. If less prominent elements are considered important by theorists, retail and industry (for example the use of product specifications), they could be focused on to improve their significance during the event. Anything that theoretically appears to be missing (for example use of formal, objective information sources such as research reports and consumer help lines provided via electronic media as well as thorough product evaluations), should be scrutinized in terms of acceptability, accessibility, applicability, etc.

Indication of role schemata A basic property of a script is that it contains person schemata, decision-making as well as role schemata. The script consequently specifies the scene (for example store visit), indicates who are involved (for example husband and wife) and provides a clearer idea of their respective roles during the activity. Roles during the decision-making event are indicated in terms of being (Jobber, 1998:59; Brinberg \& Schwenk, 1985) the initiator (instigates the process, takes lead by gathering information); influencer (attempts to persuade the other by imposing choice criteria to direct the outcome of the decision); decider (have the power and/or financial authority to make the ultimate choice); buyer (conducts the transaction) and/or the user (the actual consumer of the product which could be both, one or none of the spouses).

One of the limitations of a consumer-aid model identified by Hill and King (1989) was that the purchase of many products involves group decisions (e.g. husband and wife collectively), which have implications for the decision-making process (Punj \& Srinivasan, 1992; Burns \& Gentry, 1990; Foster \& Olshavsky, 1989; Hill \& King, 1989). Spouses might for example 
express different ideas and have different expectancies regarding household appliances (e.g. capacity, design, performance, energy consumption, price), which might lead them into using different information sources and requiring different features and standards. Despite evidence of the involvement of spouses during consumer decision-making for complex, high-risk products, the roles and decisionmaking responsibilities of spouses are seldom explicated or explained in consumer decision-making models. It has also been brought to the attention that researchers often assume certain products to be chosen and bought by women. This implies stereotyping and sexism during research that might not correctly portray what is happening in reality. The general practice to use women as subjects for consumer research when it concerns household products, while the stereotypes of male-female relations (where men are considered the experts, bosses and decision-makers and women are considered to be the passive and unquestioning followers) often still dominate. One such a study is titled Product and brand user stereotypes among social classes where 203 women were interviewed regarding households' use of cars, magazines, household appliances, toiletries, food stuffs and underwear (Munson \& Spivey, 1981). In recent years, greater emphasis has been on traditional versus modern sex roles postulating that behaviours of spouses have become less predictable because of increased flexibility and freedom associated with spouses' respective roles (Brinberg \& Schwenk, 1985). From a pragmatic standpoint men as well as women should be included in research to get a balanced view of the actual state of affairs because modern women have big spending and decision-making power that has to be acknowledged while men have increasingly become involved in household decision-making (Bristor, 1992).

Apart from spouse's involvement, the decision-making strategies implemented to reach consensus also come into play. This eventually affects the intensity of deliberation as well as the time involved at specific intervals during the event. It appears that households experience the greatest amount of conflict over individual perceptions as well as individual preferences in the more important consumer decisions (Qualls \& Jaffe, 1992). This is one of the reasons why needs assessment in the script is described as intense and complex.

Spouse's joint involvement in the acquisition of major household appliances from needs assessment up to installation of the appliance in the script, emphasizes the importance of the inclusion of men as well as women in advertising, promotions as well as literature that is made available in-stores and education programmes. Traditional consumer decision-making models do not specify role actions while this aspect is of major importance in terms of who should be targeted, in which way and where information should be made available (maybe even men's magazines). A more egalitarian approach to consumer decisionmaking, necessitates an open-minded approach where both sexes are included so that they can identify with what is offered in the market place.

\section{Script reveals issues of concern}

A comparison of the script for the acquisition of major household appliances (that is a portrayal of a specific purchasing event) and traditional consumer decisionmaking models (generalized models that represent stages of consumer decision-making and relevant concepts in interaction) provides the opportunity to confront the reality as it is anticipated and striven for by consumer facilitators, retail and industry.

\section{Limited information search On the one hand} theory postulates that consumers tend to use formal written information when complex, high-risk products are purchased (Srinivasan, 1993). On the other hand findings indicate the apparent lack of information search by consumers even when the purchase involves a large outlay of money (Ozanne, 1988). According to the script, and contrary to what is suggested for complex decision-making situations, formal, objective information sources (such as product reports, product specifications and user information provided by industry, service organizations and consumer specialists including product brochures and manuals) are neglected or not used during the decision-making process for household appliances. Money and effort spent on these sources may be wasted. During scriptelicitation procedures participants did mention that product manuals were not available (sealed in cartons) or too technical to understand. An investigation into what is required, and how it could be provided, is recommended. In a study by Wagner and Klein (1993) it was concluded that consumers in actual fact use simple agendas when purchasing even complex commodities. They reported that consumers use top down agendas (data driven, for example price, brand name) to simplify decision-making. A question worth considering is what information do consumers really consider important, relevant and desirable. How do consumers for example perceive quality (Day \& Castleberry, 1986).

Information that is used by consumers can either be categorized as promotional material (with limited educational value); personal experience (based on limited knowledge where education level and consumer socialization comes into effect) and the recommendations of trusted others (subjective information based on experience and individual preferences). Informal, subjective information thus seems to dominate consumer decisions (Cole et al, 1986). Advertisements seem to be powerful in providing information such as price and capacity: while salespeople are consulted for additional information such as guarantees and store benefits such as delivery. Salespeople are also expected to provide technical information. They are however frequently criticized for their lack of knowledge and assistance. This has to be considered a major concern by retail and industry and merits further investigation to improve the situation.

Prominence of the store in terms of product decisions In-store activity is implicated in traditional consumer decision-making models while the promi- 
nence of the retail store as indicated in the script is note worthy. Store visits seem important in terms of the type and frequency of actions that occur in-store; this scene serves as a continuation of information search, comparison-shopping and choice. The strength of in-store activities is further evidence of the importance of the store during the event. A concerted effort by retail and industry to improve the services that are provided in retail stores is required so that consumers need not depend on friends' and neighbours' subjective inputs as major information sources.

It is suggested that the in-store environment be developed as an educational facility so that consumers (who go there anyway) are given proper, non-biased assistance by well-trained salespeople. It is further suggested that the potential role of salespeople to upgrade the services provided in retail stores, be investigated. During script-elicitation procedures consumers complained about salespeople's incompetence, lack of service orientation and expressed the need for appliances to be demonstrated in the stores.

Financial decisions Financial decisions are integrated in a prominent scene in the script. This scene incorporates the deliberation of affordability, method of payment and financial arrangements. This aspect is neglected in traditional consumer decisionmaking models while it appears to be very prominent, even in a less developed script (Erasmus et al, 2002c). It is suggested that attention be given to the financial dimension of the purchase decision so that consumers have a better understanding of what they are paying for and what to expect (such as import taxes, availability of spare parts, guarantees) to reduce risk perception and to place the flow of the process (impact of financial deliberations on the final choice) and role actions (for example the sharing of financial responsibilities by spouses) in proper perspective.

\section{CONCLUSION}

The script for the acquisition of major household appliances within a consumer decision-making context is a fairly simple representation of the purchasing event but reveals much in terms of how the purchasing event is handled and which aspects need to be addressed to improve the situation as consumers experience it. The script content presents a challenge to theorists, retail and industry. It is important to acknowledge that the structure and contents of the script has the potential to reflect reality. Scripts provide the basic structure to identify and address consumers' needs in terms of actual needs rather than perceived needs; to improve the retail environment toward achieving a consumer friendly, informative environment; to recognize the interaction of spouses during decision-making to ensure that future research is non sexist and addresses all parties concerned.

It is further proposed that the script concept be ex- tended to other purchasing events such as housing and clothing decision-making as a concerted effort to have a better understanding of consumers' decisionmaking behaviour. In this way conflicting research results such as those for complex decision-making will be understood and interpreted.

\section{REFERENCES LIST}

AGRAWAL, J, RICHARDSON, PS \& GRIMM, PE. 1996. The relationship between warranty and product reliability. Journal of Consumer Affairs 30(20):421443.

AHLUWALIA, G \& SHACKFORD, A. 1998. How long will components last? Consumers' Research 81(10):21-24.

BADAMI, VV \& CHIBAT, NW. 1998. Home appliances get smart. IEEE Spectrum 35(8):36-43.

BELK, RW. 1988. Possessions and the extended self. Journal of Consumer Research 15(9):139-168.

BETTMAN, JR. 1993. The decision maker who came in from the cold. Advances in Consumer Research $X X: 7-11$

BONFIELD, EH. 1989. Understanding consumer panic. Advances in Consumer Research XVI:567573.

BOWER, GH, BLACK, JB \& TURNER, TJ. 1979. Scripts in memory for text. Cognitive Psychology 11:177-220.

BOZINOFF, L. 1982. A script theoretic approach to information processing: an energy conservation application. Advances in Consumer Research IX:481-486. BOZINOFF, L \& ROTH, VJ. 1983. Recognition memory for script activities: an energy conservation application. Advances in Consumer Research X:655-660. BRINBERG, D \& SCHWENK, D. 1985. Husband wife decision-making: an exploratory study of the interaction process. Advances in Consumer Research XII:487-491.

BRISTOR, JM. 1992. Insider versus outsider: reflections of a feminist consumer. Advances in Consumer Research XIX:843-849.

BURKE, SJ. 1990. The effects of missing information on decision strategy selection. Advances in Consumer Research XVII:250-256.

BURNS, AC \& GENTRY, JW. 1990. Toward improving household consumption behavior research: avoidance of pitfalls in using alternative household datacollection procedures. Advances in Consumer Research XVII:518-523.

BURTON, JR. 1992. Household technology: implications for research and policy. Journal of Family and Economic Issues 13(4):383-394.

CHAIKEN, S. 1980. Heuristic versus systematic information processing and the use of source versus message cues in persuasion. Journal of Personality and Marketing Psychology 39(5):752-766.

CHERIAN, J \& HARRIS, B. 1990. Capricious consumption and the social brain theory: why consumers seem purposive even in the absence of purpose. Advances in Consumer Research XVII:745-749.

COLE, CA, GAETH, G \& SINGH, SN. 1986. Measuring prior knowledge. Advances in Consumer Re- 
search XIII:64-67.

COOPER, T. 1994. Beyond Recycling. The Longer Life Option . London. New Economics Foundation.

COX, A, GRANBOIS, DG \& SUMMERS, J. 1983. Planning, search, certainty and satisfaction among durables buyers: a longitudinal study. Advances in Consumer Research X:394-399.

D'ASTOUS, A, BENSOUDA, I \& GUINDON, J. 1989. A re-examination of consumer decision-making for a repeat purchase product: variations in product importance and purchase frequency. Advances in Consumer Research XVI:433-438.

DAY, E \& CASTLEBERRY, SB. 1986. Defining and evaluating quality: the consumer's view. Advances in Consumer Research XIII:94-98.

DHAR, R. 1992. To choose or not to choose: this is the question. Advances in Consumer Research XIX:735-738.

DU PLESSIS, PJ \& ROUSSEAU, GG. 1999. Buyer Behaviour. A Multi Cultural Approach. Halfway House. International Thomson Sigma.

ENGEL, JF, BLACKWELL, RD \& MINIARD, PW. 1995. Consumer Behavior. International ed. [sl]. Dryden.

ERASMUS, AC. 1995. Die lewensduur van elektriese huishoudelike toerusting. Tydskrif vir Dieetkunde en Huishoudkunde 23(3):132-140.

ERASMUS, AC, BOSHOFF, E \& ROUSSEAU, GG. 2001. Consumer decision-making models within the discipline of consumer science: a critical approach. Journal of Family Ecology and Consumer Sciences 29:82-90. http://www.up.ac.za/academic/acadorgs/saafecs/vol29/erasmus.html

ERASMUS, AC, BOSHOFF, E \& ROUSSEAU, GG. 2002a. Script theory in consumer behaviour research. Journal of Family Ecology and Consumer Sciences 30:

ERASMUS, AC, BOSHOFF, E \& ROUSSEAU, GG 2002b. Justification of procedures for the elicitation of a script for the acquisition of household appliances within the consumer decision-making context. Journal of Family Ecology and Consumer Sciences 30:*** ERASMUS, AC, BOSHOFF, E \& ROUSSEAU, GG. 2002c. The elicitation and generation of a script for the acquisition of household appliances within the consumer decision-making context. Journal of Family Ecology and Consumer Sciences 30:***.

FIRAT, AF. 1985. A critique of the orientations in theory development in consumer behavior: suggestions for the future. Advances in Consumer Research XII:3-6.

FIRAT, AF. 1991. The consumer in post modernity. Advances in Consumer Research XVIII:70-76.

FOSTER, IR \& OLSHAVSKY, RW. 1989. An exploratory study of family decision-making using a new taxonomy of family role structure. Advances in Consumer Research XVI:655-670.

FOURNIER, S, ANTES, D \& BEAUMIER, G. 1992. Nine consumption lifestyles. Advances in Consumer Research XIX:329-337.

HANSEN, DE. 1992. Issues in consumer choice with uncertain product outcomes. Advances in Consumer Research XIX:175-176.
HARREL, GD. 1990. A new perspective on choice. Advances in Consumer Research XVII:737-745.

HILL, DJ \& KING, MF. 1989. Preserving consumer autonomy in an interactive informational environment: toward development of a consumer decision aid model. Advances in Consumer Research XVI:144151.

HIRSCHMAN, EC. 1990. Consumption styles of the rich and famous: the semiology of Saul Steinberg and Malcolm Forbes. Advances in Consumer Research XVII:850-855.

HOWELL, SC. 1994. The potential environment: home, technology and future aging. Experimerntal Aging Research 20(4):285-290.

JOAG, SG, GENTRY, JW \& HOPPER, J. 1985. Explaining differences in consumption by working and non-working wives. Advances in Consumer Research XII:582-586.

JOBBER, D. 1998. Principles and Practice of Marketing. 2nd ed. McGraw Hill. London.

KANWAR, R \& PAGIAVLAS, N. 1992. When are higher social class consumers more and less brand loyal than lower social class consumers? Advances in Consumer Research XIX:589-595.

LOFMAN, B. 1991. Elements of experiential consumption: an exploratory study. Advances in Consumer Research XVIII:729-735.

MANO, H \& DAVIS, SM. 1990. The effects of familiarity on cognitive maps. Advances in Consumer Research XVII:275-282.

MARTIN, D \& KIECKER, P. 1990. Parallel processing models of consumer information processing: their impact on consumer research methods. Advances in Consumer Research XVII:443-448.

McMEEKIN, A \& TOMLINSON, M. 1998. The diffusion of household durables in the UK. Futures 30(9):873-886.

MEYERS-LEVY, J \& MAHESWARAN, D. 1990. Message framing effects on product judgments. Advances in Consumer Research XVII:531-535.

MUNSON, JM \& SPIVEY, WA. 1981. Product and brand user stereotypes among social classes. Advances in Consumer Research VIII:696-701.

NIEMEYER, S, RAI, VK \& KEAN, R. 1997. Older females' opinions about the functionality of home products and equipment. Journal of Family and Consumer Sciences (Spring):46-49.

O'SHAUGHNESSY, J. 1985. A return to reason in consumer behaviour: an hermeneutical approach. Advances in Consumer Research XII:305-311.

OWEN, RS. 1992. Clarifying the simple assumption of the information load paradigm. Advances in Consumer Research XIX:770-776.

OZANNE, JL. 1988. Keyword recognition: A new methodology for the study of information seeking behaviour. Advances in Consumer Research XV:574579.

PUNJ, G \& SRINIVASAN, N. 1992. Influence of problem-recognition search and other decision process variables: a framework for analysis. Advances in Consumer Research XIX:491-496.

PUTO, CP. 1985. Memory for scripts in advertisements. Advances in Consumer Research XII:404- 
409.

QUALLS, WJ \& JAFFE, F. 1992. Measuring conflict in household decision behavior: read my lips and read my mind. Advances in Consumer Research XIX:522531.

RATCHFORD, BT \& VAUGHN, R. 1989. On the relationship between motives and purchase decisions: some empirical approaches. Advances in Consumer Research XVI:293-299.

SCHIFFMAN, LG \& KANUK, LL. 2000. Consumer Behavior. 7 th ed. New Jersey. Prentice Hall.

SCHURR, PH. 1986. Four script studies: What we have learnt. Advances in Consumer Research XIII:498-508.

SIRDESHMUKH, D \& UNNAVA, HR. 1992. The effects of missing information on consumer product evaluations. Advances in Consumer Research XIX:284-289.

SRINIVASAN, N. 1993. Consumer judgments, decisions and framing dynamics: An informational viewpoint. Advances in Consumer Research XX:288-290.
TIAN, KT, BEARDEN, WO \& HUNTER, GL. 2001. Consumers' need for uniqueness: scale development and validation. Journal of Consumer Research. http://www.journals.uchicago.edu/JCR/j... /issues/v28nl/280104. text.html

TOIVONEN, T. 1994. Does consumption determine social class? On the changing pattern of consumption determination. Journal of Consumer Studies and Home Economics 18:45-63.

UNGERER, LM. 1999. Activities, life styles and status products of the newly emerging middle class in Gauteng. Research Report no. 262. Unisa. Pretoria. VENKATESH, A. 1985. A conceptualization of the household/technology interaction. Advances in Consumer Research XII:189-194.

WAGNER, JA \& KLEIN, NM. 1993. The effect of familiarity on consumers' choice agendas. Advances in Consumer Research XX:209-214.

WRIGHT, ND, CLAIBORNE, CB \& SIRGY, MJ. 1992. The effects of product symbolism on consumer self concept. Advances in Consumer Research XIX:311318. 